\title{
Improvement of Low Fat Kashkaval Cheese Quality by Using Transglutaminase: b- The Impact on some Rheological Characteristics
}

\author{
Abou El-Nour, A. M.; Amira M. El-Kholy ${ }^{\varpi}$; R.A.M. Khalil; Safaa M. Mokbel and M. S. El- Safty \\ Dairy Department, Faculty of Agriculture, Suez Canal University, Ismailia 41522, Egypt
}

Received: $18 / 11 / 2020$

\begin{abstract}
Improvement of low fat Kashkaval cheese quality by using different percentages of Transglutaminase has been studied. Low fat Kashkaval cheese was made from mixture of buffalo's and cow 's milk (1:1) standardized to 1\% fat, treated by adding Transglutaminase (TGase) at the rate of $0.3,0.5$ and $0.7 \mathrm{~g} / \mathrm{Liter}$ respectively. The resultant cheese was stored for 45 days at $10^{\circ} \mathrm{C}$ and $80 \%$ relative humidity. Data showed that using Transglutaminase in low fat cheese increased moisture $\%, \mathrm{TN} \%$ and fat $\%$, while decreased acidity $\%$ as compared to low fat control cheese. Using Transglutaminase had significant positive effect on the rheological characteristic of low fat kashkaval cheese. A linear relationship was found between the concentration of TGase used and the improvement of cheese rheological properties. It could be concluded that low fat Kashkaval cheese can be made from milk treated with $0.7 \mathrm{~g}$ TGase $/ \mathrm{L}$ in order to obtain cheese of acceptable texture and good body.
\end{abstract}

Keywords: Cheese rheology, Texture profile, Transglutaminase, Kashkaval cheese

\section{INTRODUCTION}

Kashkaval cheese name is derives from the Italian cheese "Caciocavallo". It is particularly popular in Eastern Europe and Mediterranean region. The Romanians call this cheese cascaval, the Greeks kasseri while the Turkish prefer to interpret it as Ksara. Kashkaval belongs to the pasta filata cheeses. This means that the curd is given a hot bath during the production process (Alichanidis and Polychroniadou, 2008).

Low fat products especially low fat cheese had a great attention from consumers all over the world as a result of the desire to decrease the calories intake to avoid health problems and diseases. Because of that the market of low fat cheese has been grown and the manufacturers compete each other to produce high quality low fat cheese (Johansen et al., 2011). For cheese, fat is not only a nutrition factor but it is also a very important component that contributes to the cheese characteristics such as taste, functionality, appearance and rheological properties. Removing or reducing fat from cheese lead to have low quality cheese as a result of appear many defects, lacking in the distinctive cheese flavor and texture is not comparable to full fat cheeses (Koca and Metin, 2004; Ahmed et al., 2015).

One of the major problems with fat reduction in cheese is inadequate breakdown of casein and, the development of a firm texture that does not break down during mastication, unlike that observed in full-fat cheeses (Rogers et al., 2010). Creamy mouthfeel and texture provided by fat can be achieved by increasing the moisture content beyond that of full- fat cheese (Mistry, 2001). Researchers have been trying to find different ways to develop low fat cheese versions of the known cheese varieties. Approaches that have been used to improve low-fat cheese texture involve decreasing protein concentration (i.e., increasing moisture to protein ratio of the gel phase), causing greater hydrolysis of the proteins, altering protein - protein interactions or creating a bigger filler phase (Mistry, 2001; Rogers et al., 2010). One of these ways is using transglutaminase to make cross-linking bonds between milk proteins to improve the water holding capacity, texture stability, and the rheological properties of cheese (Gauche et al., 2010).

Transglutaminase (TGase) is a useful tool to change the rheological properties of caseins without damaging their special functional properties (Ozrenk, 2006). The rate of TGase cross-linking depends on the macromolecular structure of protein involved.

TGases (transglutaminases; EC 2.3.2.13) belong to a family of enzymes that catalyse an acyl-transfer reaction between the $\gamma$-carboxamide group of peptidebound glutamine residues and various primary amines, including the $\varepsilon$-amino group of endoprotein lysine residues (Özrenk, 2006).

Therefore, the aim of this study was to investigate the impact of using Transglutaminase at different dosage on some rheological properties of obtained low fat kashkaval cheese and to monitor the changes of cheese quality during the ripening period.

\section{MATERIALS AND METHODS}

\section{Materials:}

Fresh Cow's and buffalo's milk were obtained from the herd of Faculty of Agriculture, Suez Canal University, Ismailia governorate. Direct Vat yoghurt Starter (DVS) culture containing Streptococcus thermophiles and Lactobacillus delbrueckii ssp. Bulgaricus and Rennet powder, CHY-MAX were obtained from Chr-Hansen's laboratories, Denmark. Commercial salt was obtained from the local market. Calcium chloride was obtained from El-Naser pharmaceutical and chemical company, Cairo governorate, Egypt. Transglutaminase was obtained from Ajinomoto Europe Sales $\mathrm{GmbH}$, Hamburg, Germany.

\section{Experimental procedure:}

Five treatments were carried out. Treatment 1 (T1) was made from mixture of buffalo's and cow's milk (1:1) standardized to $3.25 \%$ fat to serve as full fat cheese control. The other four treatments were made from mixture of buffalo's and cow's milk $(1: 1)$ 
standardized to $1 \%$ fat, milk then divided to four portions: the first portion treatment 2 (T2) was regarded as low fat Kashkaval cheese control. Treatment 3 (T3), treatment 4 (T4) and Treatment 5 (T5) were made by adding Transglutaminase (TGase) at the rate of $0.3,0.5$ and $0.7 \mathrm{~g} /$ Liter respectively. Kashkaval cheese was made according to Simov and Ivanov (2005) as shown in Fig. (1). The levels, incubation and the inactivation temperature of TGase were used according to Ajinomoto applications data. The resultant cheese was stored for 45 days at $10^{\circ} \mathrm{C}$ and $80 \%$ relative humidity. The whole experiment was thrice. The chemical composition of standardized milk used to make full and low fat Kashkaval cheese is shown in Table (1).

Table (1): Chemical composition (\%) of standardized milk used to make low fat Kashkaval cheese (Mean value of three replicates)

\begin{tabular}{lcccc}
\hline Type of milk & TS\% & Fat\% & Casein & C/F \\
\hline Buffalo's and cow's milk (1:1) & 12 & 3.25 & 2.6 & 0.8 \\
Low fat buffalo's and cow's milk (1:1) & 9.5 & 1 & 2.6 & 2.6 \\
\hline
\end{tabular}

Cheese samples were analyzed when fresh, 15, 30 and 45 days for the chemical composition. The rheological characteristics were determined when fresh, 15 and 45 days.

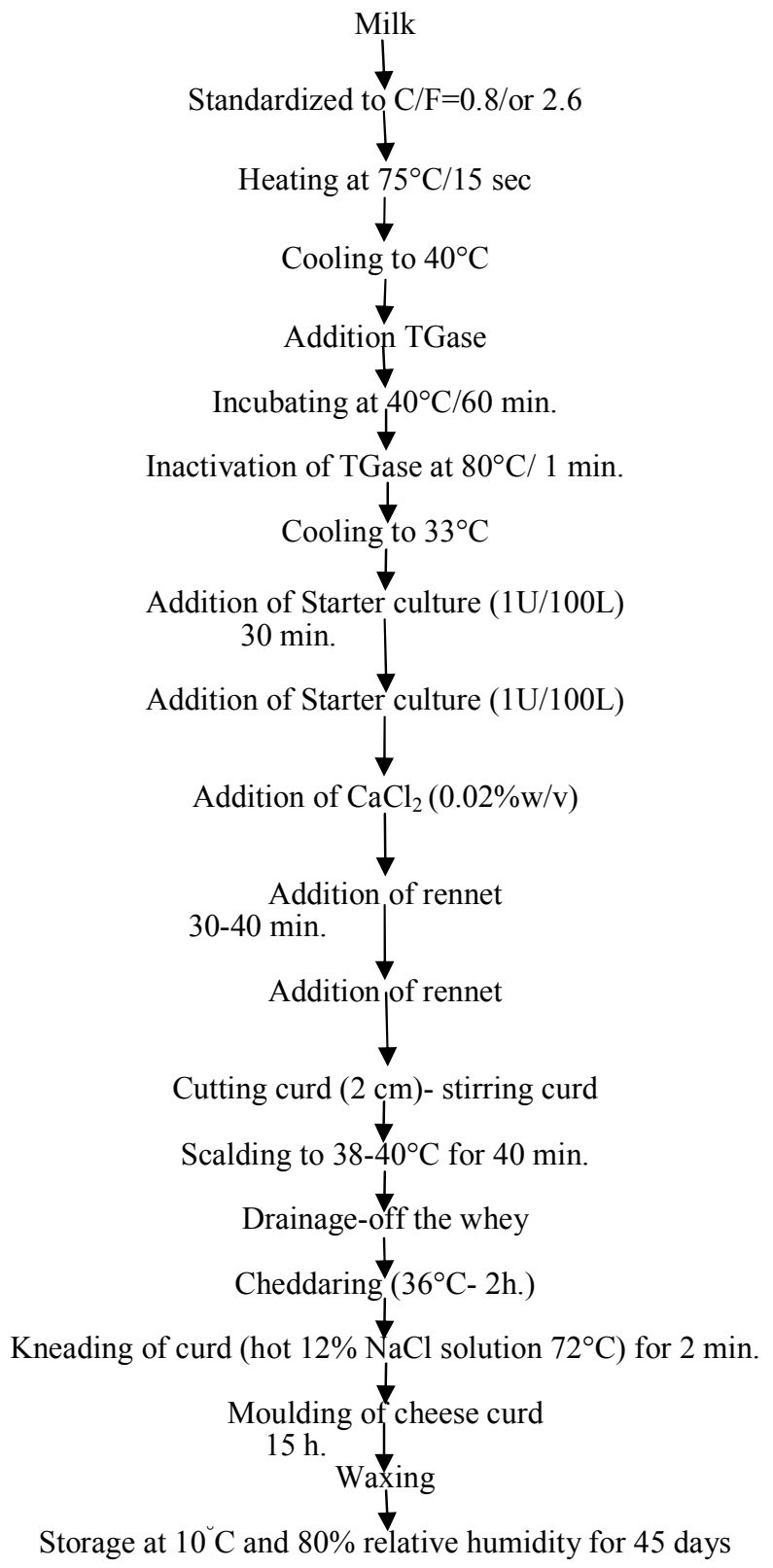

Fig (1): Flow sheet of the production of Kashkaval cheese treated with TGase 


\section{Methods of analysis:}

Analysis of cheese milk (Total solids; Fat; and Casein content) was determined according to the methods described in AOAC (2007). Cheese sample were analyzed chemically when fresh and after 15, 30 and 45 days of storage. Moisture content and total nitrogen content (TN) was measured by Kjeldahl method using semi-micro Kjeldahl were carried out according to the methods described by AOAC (2007). Acidity was determined by the titration method according to Vujicic et al. (1996) and fat content by Gerber butyrometer described by Ling (1963).

\section{Rheological properties:}

Texture profile analysis test of cheese samples (which shape was $2 \times 2 \times 2$ cylindrical) was done using a Universal Testing Machine (TMS-Pro) Food Technology Corporation, Sterling, Verginia, USA) equipped with $1000 \mathrm{~N}$ (250 lbf) load cell and connected to a computer programmed with Texture Pro ${ }^{\mathrm{TM}}$ texture analysis software (program, DEV TPA With holding time between cycle two second). A flat rod probe (49.95 $\mathrm{mm}$ in diameter) to uniaxially compresse the "cheese samples with the following parameters conduction to $30 \%$ of their original height. Each sample was subjected to two subsequent cycles (bites) of compressiondecompression.

Data were collected on computer and the texture profile parameters were calculated from (program, DEV TPA) texture analyzer and computer interface. Calculation described by Szczesniak et al. (1963) and Bourne (1978) was used to obtain the following texture profile parameters (Hardness, Cohesiveness, Springiness, Gumminess and Chewiness). The rheological characteristics were determined when fresh, 15 and 45 days of ripening.

\section{Statistical analysis:}

All measurements were done in triplicate and analysis of variance with two factorial (treatments and storage period) were conducted by the procedure of General Linear Model (GLM) using CoStat (1998) under windows software version 6.311 and least significant difference (LSD) test were employed to determine significant difference at $\mathrm{p}<0.05$.

\section{RESULTS AND DISCUSSION}

\section{Gross component of cheese:}

Moisture content is one of the macro components of any type or variety of cheese. Table (2) shows the average of moisture content of low fat Kashkaval cheese treatments. Moisture content of low fat Kashkaval cheese treatments pronouncedly $(\mathrm{p} \leq 0.05)$ higher than full-fat cheese (T1). According to Özrenk (2006) and Gauche et al. (2008), TGase-catalyzed cross-linking in casein micelles show a better water-holding capacity, meaning that more free water can be entrapped in the rennet gel network, and therefore the moisture content increases. Furthermore, the differences in moisture content between the full fat and the low fat cheese may be attributed to their protein content, i.e. a higher protein content of low fat cheese may contribute to increase water binding capacity of the cheese matrix (Romeih et al., 2002; Ahmed et al., 2015). On the other hand, the moisture content of all treatments showed a marked $(p \leq 0.05)$ decrease throughout the storage period. Similar trends were observed by Abd El-Gawad et al. (2007), and Santa and Srbinovska (2014).

Data illustrated in Table (2) showed that total nitrogen content of the resultant low fat Kashkaval cheese treatments significantly $(p \leq 0.05)$ higher than that of control full-fat (T1) when fresh and throughout the storage period. Adding Transglutaminase at all levels studied were increased significantly TN content $(\mathrm{p} \leq 0.05)$ as compared with control full-fat (T1) and control low-fat (T2) cheese. Same results were recorded by El-Kholy (2005) for low fat Tallaga cheese and Metwally et al. (2018) for low fat Mozzarella cheese. During the 45 days of storage, the TN content increased significantly $(p \leq 0.05)$ among all treatments. This increament might be due to the loss of moisture content during the storage period. These results in agreement with (Abd El-Gawad et al., 2007; Santa and Srbinovska, 2014; Talevski et al., 2017).

Fat has a great effect on the palatability of any type of cheese; it can also affect the smoothness and richness of the body and texture. With increasing the level of Transglutaminase, there was a significant $(\mathrm{P} \leq$ $0.05)$ increase in fat content as compared with control low-fat Kashkaval cheese (T2). These results are in agreement with those reported by (El-Kholy, 2005; Yanan $\mathrm{Hu}$ et al., 2013 ). Lorenzen et al. (2000), and Yanan $\mathrm{Hu}$ et al. (2013) indicated that transglutaminase can increase the gel strength of dairy products by catalyzing the covalent bond of $\varepsilon$-( $\gamma$-glutamyl) lysine. So, a stronger rennet gel catalysed by TGase can prevent rennet curd from being smashed and fracturing and hence fat loss reduced. Fat content of all treatments increased significantly $(\mathrm{P} \leq 0.05)$ during the storage time. These variations in fat content may be due to the changes in moisture content of different cheese treatments during storage period.

It is obviously clear from Table (2), that the acidity of low fat cheese treatments was lower than full fat control cheese $(\mathrm{T} 1)$. There was a significant $(\mathrm{p}<0.05)$ decrease in titratable acidity (TA) with the increase of Transglutaminase levels added. Similar results also observed by El-Kholy (2005). TA of all cheese samples had the same trend. There was a continuous increase in titratable acidity with the progressive ripening period either in the control or in the TGase treated cheese. These results were in accordance with the results for low fat Tallaga cheese given by El-Kholy (2005); Santa and Srbinovska (2014) for Galichki Kashkaval and Ahmed et al. (2015) for low fat Gouda cheese. 
Table (2): Effect of using different percentages of Transglutaminase on gross component of low fat Kashkaval cheese during ripening period (Mean value of three replicates)

\begin{tabular}{|c|c|c|c|c|c|}
\hline \multirow{3}{*}{ Treatments } & \multicolumn{4}{|c|}{ Storage period (days) } & \multirow[t]{3}{*}{ Mean } \\
\hline & Fresh & 15 & 30 & 45 & \\
\hline & \multicolumn{4}{|c|}{ Moisture content \% } & \\
\hline $\mathrm{T} 1$ & 43.5 & 42.11 & 41.60 & 41.13 & $42.09^{\mathrm{E}}$ \\
\hline $\mathrm{T} 2$ & 45.70 & 43.67 & 43.03 & 42.41 & $43.70^{\mathrm{D}}$ \\
\hline $\mathrm{T} 3$ & 46.60 & 45.10 & 44.53 & 44.00 & $45.06^{\mathrm{C}}$ \\
\hline $\mathrm{T} 4$ & 47.23 & 45.80 & 45.26 & 44.77 & $45.77^{\mathrm{B}}$ \\
\hline T5 & 47.85 & 46.37 & 45.85 & 45.37 & $46.36^{\mathrm{A}}$ \\
\hline Mean" $^{*}$ & $46.18^{\mathrm{a}}$ & $44.61^{b}$ & $44.05^{\mathrm{c}}$ & $43.54^{\mathrm{d}}$ & \\
\hline \multirow{2}{*}{ Treatments } & \multicolumn{4}{|c|}{ TN\% } & \\
\hline & Fresh & 15 & 30 & 45 & Mean \\
\hline $\mathrm{T} 1$ & 4.11 & 4.25 & 4.3 & 4.36 & $4.255^{\mathrm{D}}$ \\
\hline $\mathrm{T} 2$ & 6.22 & 6.36 & 6.49 & 6.53 & $6.400^{\mathrm{C}}$ \\
\hline $\mathrm{T} 3$ & 6.27 & 6.38 & 6.52 & 6.57 & $6.435^{\mathrm{C}}$ \\
\hline $\mathrm{T} 4$ & 6.29 & 6.44 & 6.56 & 6.61 & $6.475^{\mathrm{B}}$ \\
\hline T5 & 6.33 & 6.48 & 6.59 & 6.65 & $6.513^{\mathrm{A}}$ \\
\hline Mean" $^{*}$ & $5.844^{\mathrm{d}}$ & $5.982^{c}$ & $6.092^{6}$ & $6.144^{\mathrm{a}}$ & \\
\hline \multirow{2}{*}{ Treatments } & \multicolumn{4}{|c|}{ Fat $\%$} & \\
\hline & Fresh & 15 & 30 & 45 & Mean \\
\hline $\mathrm{T} 1$ & 27.0 & 27.9 & 28.5 & 28.8 & $28.05^{A}$ \\
\hline $\mathrm{T} 2$ & 7.9 & 8.3 & 8.4 & 8.7 & $8.33^{\mathrm{D}}$ \\
\hline $\mathrm{T} 3$ & 8.1 & 8.4 & 8.5 & 8.7 & $8.43^{\mathrm{D}}$ \\
\hline $\mathrm{T} 4$ & 8.5 & 8.7 & 8.9 & 9.0 & $8.78^{\mathrm{C}}$ \\
\hline T5 & 9.0 & 9.2 & 9.4 & 9.5 & $9.28^{\mathrm{B}}$ \\
\hline Mean $^{*}$ & $12.10^{\mathrm{d}}$ & $12.50^{c}$ & $12.74^{b}$ & $12.94^{\mathrm{a}}$ & \\
\hline \multirow{2}{*}{ Treatments } & \multicolumn{4}{|c|}{ Acidity\% } & \\
\hline & Fresh & 15 & 30 & 45 & Mean \\
\hline $\mathrm{T} 1$ & 0.99 & 1.30 & 1.33 & 1.40 & $1.26^{\mathrm{A}}$ \\
\hline $\mathrm{T} 2$ & 0.85 & 0.94 & 1.00 & 1.20 & $0.99^{\mathrm{B}}$ \\
\hline $\mathrm{T} 3$ & 0.80 & 0.87 & 0.92 & 0.96 & $0.89^{\mathrm{C}}$ \\
\hline $\mathrm{T} 4$ & 0.78 & 0.84 & 0.88 & 0.93 & $0.86^{\mathrm{D}}$ \\
\hline $\mathrm{T} 5$ & 0.75 & 0.81 & 0.86 & 0.89 & $0.83^{\mathrm{E}}$ \\
\hline Mean* & $0.83^{\mathrm{d}}$ & $0.95^{\mathrm{c}}$ & $0.99^{\mathrm{b}}$ & $1.08^{\mathrm{a}}$ & \\
\hline
\end{tabular}

T1: control full fat, T2: control low fat, T3: 0.3 gTGase/L, T4: $0.5 \mathrm{~g}$ TGase/L, T5: 0.7 g TGase/L.

*a, b, c \& d and A, B, C \& D: means with the same letters among treatments and storage period respectively are not significantly different $(\mathrm{p}>0.05)$

\section{Rheological Characteristics:}

Rheology of cheese, defined as the study of their deformation and flow when subjected to a stress or strain. The behavior of the cheese when subject to these stresses or strain is referred by descriptive terms such as hardness, firmness, springiness, crumbliness or adhesiveness. Cheese rheology is a function of its composition, microstructure, the physicochemical state of its components and the macrostructure (Fox et al. 2017).

Hardness of cheese can be defined as high resistance to deformation by applied stress (Fox et al.
2000). From Table (3), It is clear that the decreasing of fat affect the hardness of the kashkaval cheese. low-fat kashkaval cheese treatments had higher $(\mathrm{P}<0.05)$ hardness values than the full-fat control (T1). These results are coincided with Ya-nan $\mathrm{Hu}$ et al. (2013), Ahmed et al. (2015). Rudan et al. (1999), explained that the increase of hardness was due to the decrease of the fat content and total filler volume and the increase of the amount of matrix (protein). Although the moisture content increased, it did not completely offset the decrease in fat as indicated by the steady increase in protein content with the reduction of fat content. 
Adding TGase decreased the hardness of the lowfat cheese significantly $(\mathrm{P} \leq 0.05)$. Transglutaminase improved the hardness of low fat treatments due to the cross-linking of protein occurred by TGase in the resultant cheese (Bonisch et al., 2007). Moreover, the use of TGase in the production of low-fat cheese increased the water-holding capacity, emulsification, foaming, viscosity and solubility in the final product (Li- Chan, 2004). These results in accordance with Yanan $\mathrm{Hu}$ et al. (2013) and Ahmed et al. (2015). During the storage period the hardness increased up to the day 15 and then decreased significantly $(\mathrm{P}<0.05)$ at the end of the storage. The decrease in hardness at the end of the storage period is according to cheese proteolysis. Pierro et al. (2010) reported that the reduction of hardness of TG- treated cheeses during early ripening was probably because of proteolysis.

Fox et al. (2000) defined the springiness as the tendency of a deformed material to recover to its undeformed condition after removal of deformation stress. It can be noticed from Table (3) that full fat control cheese (T1) had the highest $(\mathrm{P} \leq 0.05)$ springiness value among all treatments while, low fat control cheese (T2) had the lowest $(\mathrm{P} \leq 0.05)$ value. This result may be due to that decreasing fat content in cheese matrix have more compact protein matrix with less open spaces that would be occupied by milk fat globule (Bryant et al., 1995). Fox et al. (2000) stated that as concentration of casein in cheese matrix increases, the intra- and inter-strand linkages become more numerous and the matrix displays greater elasticity and more difficult to deform and more Springer. In contrast of the current study Koca and Metin (2004) reported that full- fat Kashar cheese had significantly lower springiness values than low fat cheese during ripening. Adding Transglutaminase increased springiness values in the low fat Kashkaval cheese treatments T3, T4 and T5 respectively. These results in agreement with Ya-nan $\mathrm{Hu}$ et al. (2013). In all treatments springiness values decreased with storage progressed.

The cohesiveness is explained as the ratio of the shape of the resistance to the second compression to the behavior of the compression (Fox et al., 2000; Tunick, 2000). It was found that the mean of cohesiveness value of low fat control cheese was higher than that of full-fat cheese (Table 3). Adding Transglutaminase to the low fat Kaskaval cheese treatments decrease the cohesiveness. This may be due to the increase in the moisture content by adding Transglutaminase. During ripening periods the cohesiveness increased up to 15 days then decreased by the end of ripening.

Table (3): Effect of using different percentages of Transglutaminase on the hardness, Springiness and Cohesiveness of low fat Kashkaval cheese during ripening period (Mean value of three replicates)

\begin{tabular}{|c|c|c|c|c|}
\hline \multirow{3}{*}{ Treatments } & \multicolumn{3}{|c|}{ Storage period (days) } & \multirow{3}{*}{ Mean } \\
\hline & Fresh & 15 & 45 & \\
\hline & \multicolumn{3}{|c|}{ Hardness (N) } & \\
\hline T1 & 19.2 & 33.0 & 24.8 & $25.67^{\mathrm{E}}$ \\
\hline $\mathrm{T} 2$ & 25.3 & 49.5 & 37.2 & $37.33^{\mathrm{A}}$ \\
\hline $\mathrm{T} 3$ & 22.9 & 45.5 & 33.0 & $33.80^{\mathrm{B}}$ \\
\hline $\mathrm{T} 4$ & 21.1 & 44.7 & 29.5 & $31.77^{\mathrm{C}}$ \\
\hline T5 & 20.5 & 43.3 & 25.3 & $29.70^{\mathrm{D}}$ \\
\hline Mean* & $21.8^{\mathrm{c}}$ & $43.2^{\mathrm{a}}$ & $29.96^{b}$ & \\
\hline \multicolumn{5}{|c|}{ Springiness (mm) } \\
\hline $\mathrm{T} 1$ & 4.52 & 2.36 & 1.82 & $2.90^{\mathrm{A}}$ \\
\hline $\mathrm{T} 2$ & 4.30 & 1.97 & 1.62 & $2.63^{\mathrm{D}}$ \\
\hline $\mathrm{T} 3$ & 4.37 & 2.2 & 1.67 & $2.75^{\mathrm{C}}$ \\
\hline $\mathrm{T} 4$ & 4.40 & 2.25 & 1.71 & $2.79^{\mathrm{C}}$ \\
\hline T5 & 4.44 & 2.29 & 1.77 & $2.83^{\mathrm{B}}$ \\
\hline Mean* & $4.41^{\mathrm{a}}$ & $2.21^{\mathrm{b}}$ & $1.72^{\mathrm{c}}$ & \\
\hline \multicolumn{5}{|c|}{ Cohesiveness (Ratio) } \\
\hline $\mathrm{T} 1$ & 0.70 & 0.90 & 0.73 & $0.78^{D}$ \\
\hline $\mathrm{T} 2$ & 0.79 & 0.99 & 0.85 & $0.88^{\mathrm{A}}$ \\
\hline $\mathrm{T} 3$ & 0.77 & 0.96 & 0.83 & $0.85^{\mathrm{AB}}$ \\
\hline $\mathrm{T} 4$ & 0.76 & 0.95 & 0.80 & $0.84^{\mathrm{BC}}$ \\
\hline T5 & 0.74 & 0.93 & 0.78 & $0.82^{\mathrm{C}}$ \\
\hline Mean* & $0.75^{c}$ & $0.95^{\mathrm{a}}$ & $0.80^{b}$ & \\
\hline
\end{tabular}

Gumminess is described as breaking force required to ingest a semi-solid food easily (Raphielides et al., 1995). Table (4) shows that gumminess values of low fat control cheese (T2) and low fat treatment (T3) exhibit higher $(\mathrm{P} \leq 0.05)$ values of Gumminess than full fat control cheese (T1). This may be due to the high hardness values corresponding to those low fat cheese treatments. Full-fat cheese had significantly $(\mathrm{P} \leq 0.05)$ lower Gumminess values than low fat cheese during storage. Adding Transglutaminase decreased the 
gumminess of the low fat cheese treatments T3, T4 and T5 respectively as compared to low fat control cheese (T2). This may be due to the reduction of hardness by adding Transglutaminase. Gumminess of all treatments increased significantly $(\mathrm{P} \leq 0.05)$ up to 15 days and then decreased significantly $(\mathrm{P} \leq 0.05)$ at the end of ripening period.

Chewiness is defined as required chewing force to make a solid food ready for ingesting (Raphielides et al., 1995). Chewiness values (Table 4) of low fat Kashkaval cheese treatments are higher $(\mathrm{P} \leq 0.05)$ than that of full fat control cheese (T1). This may be due to the higher hardness values of low fat cheese treatments. It could be noticed that adding Transglutaminase decrease significantly $(\mathrm{P} \leq 0.05)$ the chewiness values of treatments T3, T4 and T5 respectively. Chewiness of all treatments increased significantly $(\mathrm{P} \leq 0.05) \quad$ With prolonged ripening period up to 15 days then decline significantly $(\mathrm{P} \leq 0.05)$ at the end of ripening period.

It was noticed that treatment $5(0.7 \mathrm{~g}$ TGase/L) gained the highest score for all texture profile properties and overall acceptability among all low fat Kashkaval cheese treatments when fresh and throughout storage period.

Table (4): Effect of using different percentages of Transglutaminase on the Gumminess and Chewiness of low fat Kashkaval cheese during ripening period (Mean value of three replicates)

\begin{tabular}{|c|c|c|c|c|}
\hline \multirow{3}{*}{ Treatments } & \multicolumn{3}{|c|}{ Storage period(days) } & \multirow{3}{*}{ Mean } \\
\hline & Fresh & 15 & 45 & \\
\hline & \multicolumn{3}{|c|}{ Gumminess (N) } & \\
\hline T1 & 13.44 & 29.70 & 18.1 & $20.41^{\mathrm{E}}$ \\
\hline $\mathbf{T 2}$ & 19.99 & 49.05 & 31.62 & $33.55^{\mathrm{A}}$ \\
\hline T3 & 17.63 & 43.68 & 27.39 & $29.57^{\mathrm{B}}$ \\
\hline T4 & 16.04 & 42.47 & 23.60 & $27.37^{\mathrm{C}}$ \\
\hline T5 & 15.17 & 40.27 & 19.73 & $25.06^{\mathrm{D}}$ \\
\hline \multirow[t]{2}{*}{ Mean* } & $16.46^{\mathrm{c}}$ & $41.03^{a}$ & $24.09^{b}$ & \\
\hline & \multicolumn{3}{|c|}{ Chewiness (N) } & \\
\hline T1 & 60.75 & 70.09 & 32.94 & $54.59^{\mathrm{E}}$ \\
\hline $\mathbf{T} 2$ & 85.96 & 96.54 & 51.22 & $77.91^{\mathrm{A}}$ \\
\hline T3 & 77.04 & 96.10 & 45.74 & $72.96^{\mathrm{B}}$ \\
\hline T4 & 70.58 & 95.56 & 40.36 & $68.83^{\mathrm{C}}$ \\
\hline T5 & 67.35 & 92.22 & 34.92 & $64.83^{\mathrm{D}}$ \\
\hline Mean* & $72.34^{b}$ & $90.10^{\mathrm{a}}$ & $41.04^{\mathrm{c}}$ & \\
\hline
\end{tabular}

The results obtained in this study indicate that using Transglutaminase improved low fat Kashkaval cheese rheological characteristics when fresh and along storage period. A linear relationship was found between the concentration of TGase used and the improvement of cheese rheological properties. The cross-linking of protein occurred by TGase led to decrease the hardness of the resultant cheese. A significant positive correlation among these three TPA parameters (hardness, gumminess and chewiness) was found. It was observed that both the difference of means and the changes in the hardness values of all cheeses showed a similar trend to the changes in the gumminess and chewiness values during storage.

The addition of Transglutaminase to low-fat kashkaval cheese highly improved overall acceptability. It could be concluded that low fat cheese can be made from milk treated with $0.7 \mathrm{~g}$ TGase/L in order to obtain cheese of acceptable texture and good body.

\section{REFERENCES}

Abd El-Gawad Mona, A. M., Reda A. M. Sabek and Nagla A. Hegazi (2007). Quality and properties of low-fat buffaloe 's kashkaval cheese. International Journal of Dairy Science, 2(3): 244-251.

Ahmed, M. A., Amal M. M. El-Nimer, M. A. Mostafa and H. Omar (2015). Effect of fat replacer or transglutaminase on the quality of low-fat Gouda-like cheese. World Journal of Dairy \& Food Sciences, 10(2): 170-180.

Alichanidis, E. and A. Polychroniadou (2008). Characteristics of major traditional regional cheese varieties of east mediterranean countries: a review. Dairy Science and Technology, 88(4-5): 495-510.

AOAC (2007). Official methods of analysis $18^{\text {th }}$ ed., Association of Official Analysis Chemists Inc., USA

Bourne, M. C. (1978). Texture profile analysis. Food Technology, 32: 62-67. 
Bryant, A., Z. Ustunol and J. Steffe (1995). Texture of Cheddar cheese as influenced by fat reduction. Journal of Food Science, 60(6): 1216-1220.

Costat (1998). Users manual for Costat version 6.311. Cohort soft ware; Berkeley; CA.

El-Kholy, A. M. (2005). Influence of Tansglutaminase (TGase) Enzyme on the Quality of Low Fat Tallaga Cheese. Journal of Agricultural Science, Mansoura University, 30(9): 54075418.

Fox, P. F., T. P. Guinee, T. M. Cogan and P. L. H. McSweeney (2000). Cheese Rheology and Texture, In Fundamental of Cheese Science, Aspen Publications, USA, pp. 305-324.

Fox, P. F., T. P. Guine, T. M. Cogan and P. L. H. McSweeney (2017). Cheese, Structure, Rheology and Texture in Fundamentals of Cheese Science. $2^{\text {nd }}$ Edition Springer, New York, pp 475-532.

Gauche, C., P. L. M. Barreto and M. T. Bordignon-Luiz (2010). Effect of thermal treatment on whey protein polymerization by transglutaminase: Implications for functionality in processed dairy foods. LWT- Food Science and Technolology, 43(2): 214- 219.

Gauche, C., J. T. C. Vieira, P. J. Ogliari and M. T. Bordignon-Luiz (2008). Cross-linking of milk whey proteins by transglutaminase. Process Biochemistry, 43(7): 788-794.

Johansen, S. B., T. Nas and M. Hersleth (2011). Motivation for choice and healthiness perception of calorie-reduced dairy products. A cross-cultutal study. Appetite, 56(1): 15-24.

Koca, N. and M. Metin (2004). Textural, melting and sensory properties of low fat fresh kashar cheese produced by using fat replacers. International Dairy Journal, 14(4): 365-373.

LI-Chan, E. C. Y. (2004). Properties of proteins in food systems: An introduction. In Proteins in food processing, CRC press Boca Raton, FL., pp: $2-26$.

Ling, E. R. (1963). Text Book of Dairy Chemistry. Vol. 2. Practical, $3^{\text {rd }}$ ed., Chapman and Hall limited, London.

Lorenzen, P. Chr., A. Mautner and E. Schlimme (2000). Enzymatic cross-linking of proteins in the production of milk products. Proceedings of $1^{\text {st }}$ International symposium of enzymatic protein processing- ISEPP-1 (H. Gruppen, W. Vanharingsveldt, Eds) TNO nutrition and Food Research Institute, Zeist, the Netherlands, 163.

Metwally, M. M. E., H. M. El-Zeini and E. F. Gazar (2018). Impact of Using Transglutaminase Enzyme in Manufacturing Low and High Fat Mozzarella Cheese. Journal of Food, Nutrition and Population Health, 2(1): 1-5.

Mistry, V. V. (2001). Low fat cheese technology. International Dairy Journal, 11(4): 413-422.

Özrenk, E. (2006). The use of transglutaminase in dairy products. International Journal of Dairy Technology, 59(1): 1-7.
Pierro, P. D., L. Mariniello, A. Sorrentino, C. V. L. Giosafatto, L. Chianese and R. Porta (2010). Transglutaminase-Induced Chemical and Rheological Properties of Cheese. Food Biotechnology, 24(2): 107-120.

Raphaelides, S., K. D. Antoniou and D. Petridis (1995). Texture evaluation of ultra filtered teleme cheese. Journal of Food Science, 60(6): 1211-1215.

Romieh, E. A., A. Michaelidou, C. G. Biliaderis and G. K. Zerfiridis (2002). Low-Fat white-brine cheese made from bovine milk and two commercial fat mimetics. Chemical, Physical and Sensory attributes. International Dairy Journal, 12(6): 525-540.

Rogers, N. R., D. J. McMahon, C. R. Daubert, T. K. Berry and E. A. Foegeding (2010). Rheological properties and microstructure of Ched-dar cheese made with different fat contents. Journal of Dairy Science, 93(10): 4565-4576.

Rudan, M. A., D. M. Barbano, J. J. Yun and P. S. Kindstedt (1999). Effect of fat reduction on chemical composition, proteolysis, functionality, and yield of Mozzarella cheese. Journal of Dairy Science, 82(4): 661672.

Santa, D. and S. Srbinovska (2014). Traditional production and main characteristics of Galichki Kashkaval. Mljekarstvo, 64(2): 119-126.

Seguro, K., N. Nio and M. Motoki (1996). Some characteristics of a microbial protein crosslinking enzyme: Transglutaminase. in: Macro Molecular Interactions in Food Technol., edited by Parris, N; A. Kato; L. K. Creamer; J. Pearce, ACS Symposium Series 650, American Chemical Society Columbus, OH. pp. 271-280.

Simov, Zh. I. and G. Y. Ivanov (2005). Proteolytic activity of Lacctobacillus delbrueckii ssp. bulgaricus and Streptococcus thermophilus in frozen-stored kashkaval cheese. Journal of Industrial Microbiology \& Biotechnology, 32 (10): 449-454.

Szczesniak, A., M. Brandt and H. Freidman (1963). Development of Standard Rating Scales for Mechanical Parameters and Correlation between the Objective and the Sensory Methods of Texture Evaluation. Journal of Food Science, 28(4): 397-403.

Talevski, G., S. Srbinovska, D. Santa and N. Mateva (2017). Influence of packaging on Kashkaval quality. Mljekarstvo, 67(1): 25-32.

Tunick, M. H. (2000). Rheology of Dairy Foods that Gel, Stretch, and Fracture. J Dairy Science, 83(8): 1892-1898.

Vujicic, I. F., M. Skrinjar and M. Vulic (1996). Role of protease from Penicillium roqueforti in the modification of cheese slurry and Trappist cheese ripening. Acta Alimintaria, 25(1): 1525. 
White, C. H. (1993). Rapid methods for estimation and prediction of shelf-life of milk and dairy products. Journal of Dairy Science, 76(10): 3126-3132.

Ya-nan, Hu., Ge Ke-shan, Jiang Lu, Guo Hui-yuan, Lio Jie, Wang Fang and Ren Fa-zheng (2013).
Effect of Transglutaminase on Yield, Compositional and Functional Properties of Low-fat Cheddar Cheese. Food Science and Technology Research, 19(3): 359-3677.

\section{تحسين جودة جبن الكثكفال المنخفض الدهن باستخدام الترانس جلوتامينيز: بـ التأثير على الته

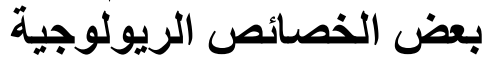

عاطف محمد أبو النور، أميرة محمد الخولى، رفيق عبد الرحمن خليل، صفاء محمود مقبل، محمد سميح الصفتى

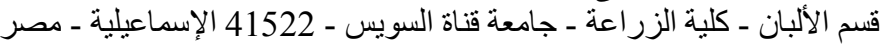

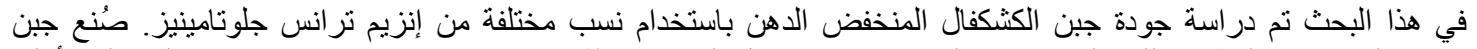

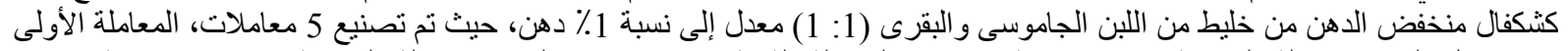

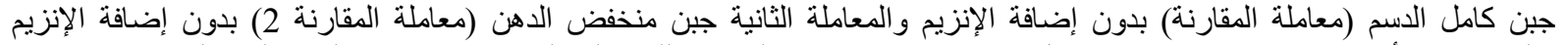

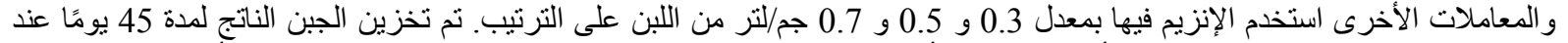

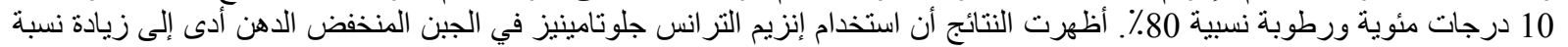

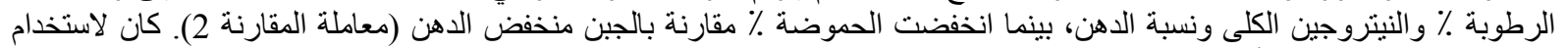

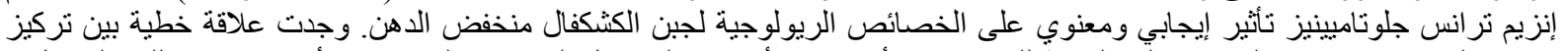

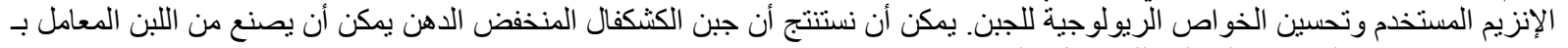
0.7 جر ام تر انس جلوتامينيز/لتر لبن للحصول على جبن ذو قو ام وتركيب جيد. 